\title{
New report of Laophonte cornuta Philippi,1840 (Copepoda: Harpacticoida) from the coral area, North of Tioman Island, South China Sea
}

\author{
Azrina Sham ${ }^{a}$, Zaleha Kassim ${ }^{a,{ }^{*}}$, Zuhairi Ahmad $^{\mathrm{a}}$, Ahmad Ismail ${ }^{\mathrm{b}}$ \\ a Marine Science Department, Kulliyyah of Science, International Islamic University Malaysia, Jln. Sultan Ahmad Shah, 25200 Kuantan, Pahang, \\ Malaysia \\ ${ }^{b}$ Department of Biology, Faculty of Science, Universiti Putra Malaysia, 43400 UPM Serdang, Selangor, Malaysia \\ * Corresponding author: drzack@iium.edu.my
}

\section{Article history}

Received 18 February 2019

Revised 21 April 2019

Accepted 26 June 2019

Published 15 April 2020

\begin{abstract}
Laophonte cornuta Philippi 1840 was first reported in rather temperate regions and later noted to extend their distribution to the warmer coasts. The earlier reports were based on specimen collected from bottom vegetation or sediment enriched in organic matter. The present study was carried out during the warm month phenomenon which struck coral areas in the South China Sea in 2016. Sediment core samples were collected by SCUBA divers in the coral areas at Pulau Tulai $\left(2^{\circ} 54^{\prime} 24.84^{\prime \prime N}, 104^{\circ} 5^{\prime} 57.67 " \mathrm{E}\right)$ and Batu Malang (2 $\left.52^{\prime} 29.98 " \mathrm{~N}, 104^{\circ} 8^{\prime} 47.92^{\prime \prime} \mathrm{E}\right)$, in the northern part of Tioman Island. The bottom substrates were covered by mostly dead corals and coral rubbles. Taxonomic observation was carried out following the sorting and microscopic dissection process in the laboratory. The denticulate margin of somites along with blunt short spinules distributed on the surface as shown from the Scanning Electroscopic Microscopy (SEM) observation proves their morphological adaptation to survive between the coral rubbles and gravels in the study area. Other variation found is on the size of the caudal rami which is very much slender than those reported from colder regions. Except for the setae formula, it shared similar characters with $L$. paradduensis reported from Maldives and $L$. aeutirostris from Monterey Bay. The present specimen also shared some variation found in specimen reported from the Andaman Sea. L. cornuta reported from the Tioman Island might be able to endure the harsh environment due to their robust feature of the body surface.
\end{abstract}

Keywords: Taxonomy, Harpacticoida, coral area, Laophontidae, South China Sea

\section{INTRODUCTION}

Copepod study in Malaysia are mainly focusing on their ecology [1],[2],[3] and as live feeds [4],[5]. Taxonomic study on harpacticoid copepods in Malaysia is still scarce and draw interest of very few researchers. Typically found from ecological surveys on coral reef areas of Tioman Island, meiobenthos samples were dominated by the harpacticoid copepods.

Family Laophontidae T. Scott of harpacticoid copepod has more than 262 species of 63 genera as reported by [6]. In 2018, [7] added that the number has increased to 327 species and subspecies. Laophontids have several types of living modes depending on their occurrences. For instance, Echinolaophonte armiger were found associated with mangroves in Columbian wetland [8], while genera Apistophonte and Propephonte were found associated with dead corals in Kenyan coast [9]. These genera could also be found in the estuary and brackish water such as those of Apolethon laophontid from Korean water [10]. Some other could also be found in organic-rich sediment of oil drilling area offshore Mexico as shown in a report on Laophonte and Paralaophonte [11].

The taxonomic study for this family is complex. According to [12] Huys (1990), the superfamily of Laophontidae can be defined on the basis of the following apomorphies: (1) antennules with outer spinous process on segment 2; (2) antenna with allobasis bearing 1 seta; (3) antennary exopod quadrisetose; (4) P1 exopod without inner seta on exp-2 and 4 setae/spines on exp-3; (5) P1 endopod 2-segmented with elongated enp-1 and 2 elements on enp-2; (6) P2-P4 with 2-segmented endopods; exp-1 without inner seta; (7) sexual dimorphism of P3 endopod; (8) P6 bisetose with one member fused to somite.

The genus Laophonte has 158 direct children from the parent Laophontidae Scott T., 1904 [13] while there are 29 species representing this genus from the European marine harpacticoids [14]. Its distribution is considered worldwide as it can be found in the Indian Ocean, North Sea, North Atlantic Ocean, and the Economic Exclusive Zone of New Zealand.

Laophonte cornuta Philippi, 1840 was first reported from rather temperate regions. [15] included L. cornuta in the cornuta-group as having a 'spur' on the second antennule segment and based on female P5 of cornuta-type. [16] also described the group as having foursegmented female antennule, having antennule segment I and II with acute thorn, caudal rami with the size twice as long as it is broad, P1 exopod and P4 endopod of 2-segmented, P5 exopod with 6 setae, and the baseoendopod with 5 setae.

This study aimed to report the occurrence of $L$. cornuta from this similar coral habitat and to examine the ultra-structure of the body surface that could be related to their life strategy in the coral area. 


\section{MATERIALS AND METHODS}

Samples of harpacticoids were collected from coral areas in several locations at the northern part of Tioman Island of the South China Sea (Fig.1). The fieldwork was meant for ecological monitoring of coral ecosystem during the incident of the 2016 warmest months as reported in relation to sea surface temperature (SST) dataset. A Geographic Information System (GIS) method was adopted for structural aerial surveys of the sampling areas [17]. Hand cores collection were obtained by scuba divers at the sea bottom of Tulai Island $\left(2^{\circ} 54^{\prime} 24.84^{\prime \prime} \mathrm{N}, 104^{\circ}\right.$ $\left.5^{\prime} 57.67^{\prime \prime E}\right)$ and Batu Malang (2॰52'29.98"N,104 8'47.92"E). Samples were fixed with $5 \%$ buffered formalin and brought back to the laboratory for further analyses.

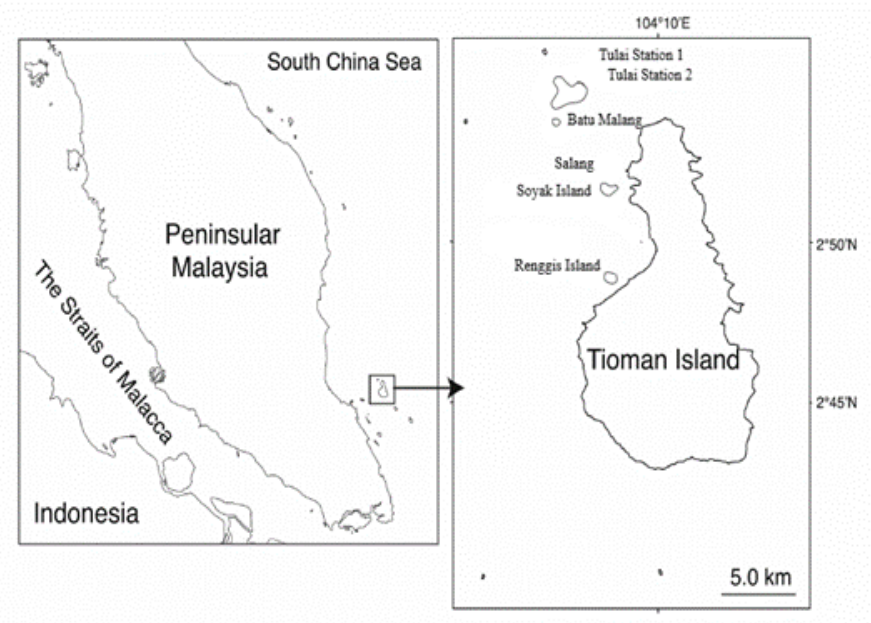

Fig. 1. Map of the sampling area in Tulai and Batu Malang in Tioman Island.

Harpacticoid specimens were sorted, isolated, and further observed under a stereo microscope before being dissected into parts of cephalothorax, thoracic somites, urosomites, and caudal rami in $50 \%$ glycerol media [18]. Separate slides were prepared with CMCP9 media for the dissected parts, which were later examined and drawn with the aid of Lucida camera attached to a compound microscope (Leica DM500). These characters were examined and referred to the reports of [19],[16],[20],[12] and [6]. Specimens used for the descriptions were kept in the marine museum of Kulliyyah of Science, International Islamic University Malaysia, Kuantan campus. Paratypes were stored in alcohol and kept in the museum as well. Some specimens were also prepared for the examination of the ultra-structure of morphology using Scanning Electron Microscopic (SEM). All specimens were rinsed to discard the residual formalin before a series of alcohol dehydration, critical point-drying, and gold coating procedures, and then later examined under a Scanning Electron Microscope [21].

The descriptive nomenclature written in this article was adapted from [16],[20],[22] and [23]. All setae arrangements for the setal formula were adopted from [22].

\section{RESULTS AND DISCUSSION}

\section{Sea bottom condition}

The sampling areas, Tulai Island and Batu Malang, were both tourism spots located at the northern part of Tioman Island. Aerial photos of both areas were reported in [17].

Batu Malang is a small rock island just to the south of Tulai Island. [17] reported on the dense coral area on its sea bottom as detected using GIS technique. Most of the surveyed areas were covered with live corals with some bright colour area that represented dead corals.

\section{Species descriptions}

Order Harpacticoida Sars, 1903

Family Laophontidae T. Scott, 1904

Genus Laophonte Philippi, 1840
Laophonte cornuta Philippi, 1840 (Fig. 2: A,B,C,D,E and Fig. 3)

4 Females dissected; 5 Females prepared for SEM

Locality: Batu Malang (2॰52'29.98"N, 104 8'47.92"E), Tioman

Island Malaysia

Paratype location: Pulau Tulai (254'24.84"N, 104 5'57.67"E),

Tioman Island Malaysia

Female. The body is moderately slender and tapering continuously towards the tip of caudal rami. Total length is $470 \mu \mathrm{m}$ from the terminal of cephalothorax towards the caudal rami.

Mouthpart

Maxiliped (Fig. A). The basis is long with a row of spinules on the anterior surface and distal margin. The first endopod segment is with a row of spinules on the anterior surface and the second endopod with a long claw.

Body

The body surface has strong integuments with blunt spinules. On the dorsal part, each somite is bordered by jagged and denticulate spines (Fig. C). The last urosomite which is anal somite almost rectangular and anal operculum ornamented with a raised strong spine and minute hairs (Fig. D). Caudal rami is greatly slender and expanded, length is more than twice as width, with moderate transverse rows of spinules at the edge and one long spinule grows at the outer layer (Fig. E).

\section{Head}

Antennule. It is four-segmented. Segment 1 and 2 are broad and subequal in length. Segment 2 is well-developed with unguiform projection. Segment 3 is the longest with most setae. Aesthetacs are on segment 3 and segment 4 .

Antenna. The coxa is bare and small with chitinous allobasis and a row of spinules and a spine on the edge surface. Exopod is one-segmented with four intermediate-sized setae. Endopod has one slender seta at the distal corner and five markedly different setae at the terminal: two naked setae, two geniculate setae, and one half-sided serrated setae.

\section{Legs, P1-P5}

P1 (Fig. B). The coxa widened with a long row of spinules on the surface. Spinules are present at the outer lateral. Basis has one slender seta at the inner margin. Exopod is two-segmented. Exp-1 has 1 outer lateral seta and 2 longitudinal rows of spinules on the anterior surface. Endopod is two-segmented. Enp-1 is bare, enp-2 with strong claw, and one minute setule at the terminal.

Setae formula for P2-P4:

$\begin{array}{lll}\text { Leg } & \text { Exopod } & \text { Endopod } \\ \text { P2 } & 0.1 .123 & 1.220 \\ \text { P3 } & 0.1 .223 & 1.321 \\ \text { P4 } & 0.1 .223 & 1.221\end{array}$

P5 (Fig.3). The baseoendopod is separated from the exopod and having 6 plumose setae. The exopod is ovoid in shape and smaller if compared to the baseoendopod. The exopod has 3 long spinulose setae.

\section{Remarks}

A distinct feature of $L$. cornuta reported from Tioman Island was the long and slender caudal rami almost similar with one of the variations found in $L$. cornuta population from Andaman and Nicobar Islands [19]. The variation seems common as there were also specimens with similar caudal rami almost rectangular or as trice of length as width from the areas. These features were almost the same as Laophonte aeutirostris first described by [20] from Monterey Bay despite differences in major characters such as its setal formula.

The current specimen agreed well with the description from the West Indian Islands [24] except for the size of the caudal rami which were longer. This is also contrasted with the recent description of $L$. cornuta [25] for the samples from Easter Island. The specimen also 
shared similar characters with L. paradduensis reported from Maldives except for the setal formula of exopod of P2 (setal formula: 0.1.122) as described by [8].

It is interesting to note that most of the L. cornuta were reported from seaweeds wash, sediment, and organic-enriched sediment. The present specimens were collected from a coral reef area of Tioman Island. Some differences particularly on the ornamentation found on the body surface indicated the specific adaptation to the coral-line and coral rubble condition. The ends of somites were armed with denticulate margin, while coarse spinules were distributed on the surface of somite. [20] emphasised on the smooth to some rigged somite margin found in the reported specimen. The ultrastructure
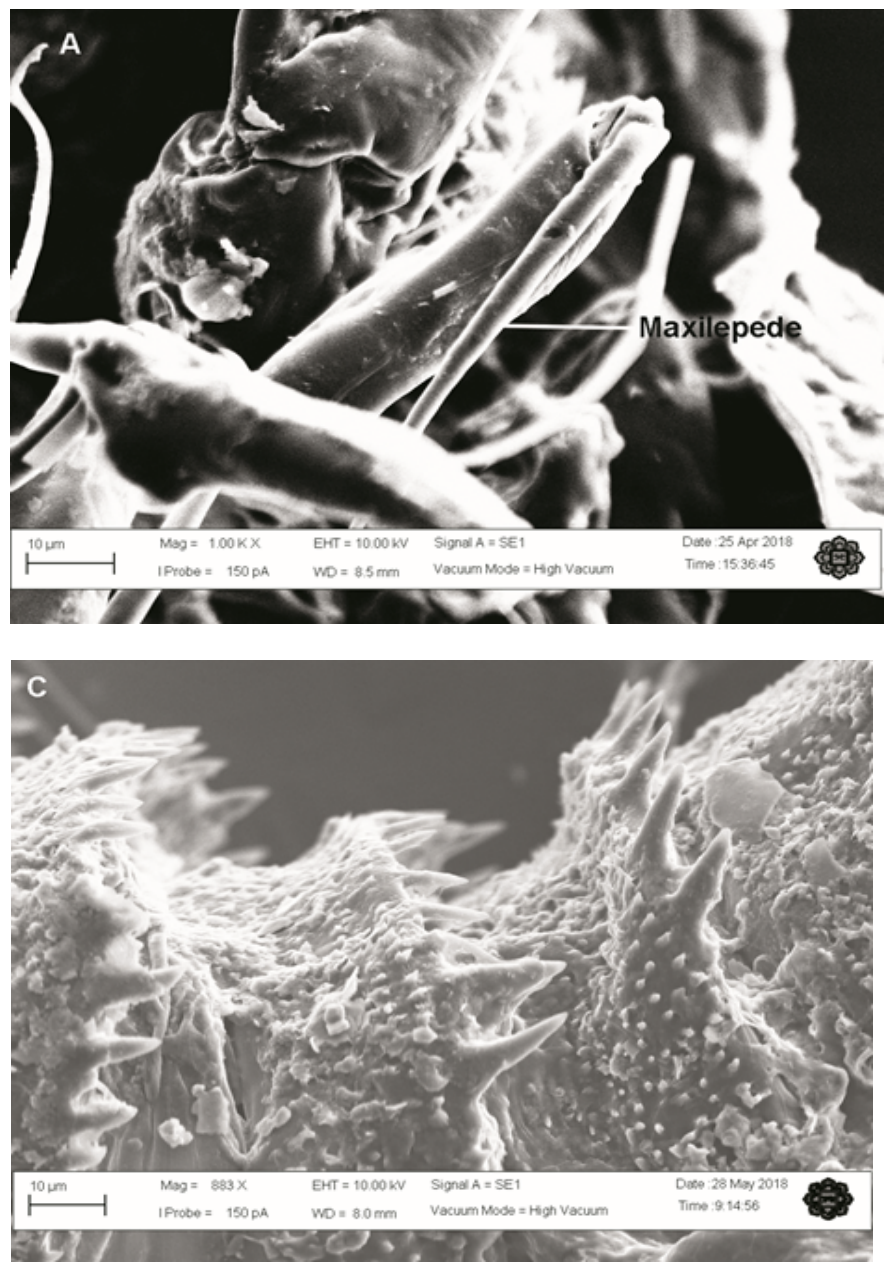

seemed correlated with the habitat type to ease their movement between the hard structures of rubbles and coral skeletal surface. The ultrastructures shown by the SEM micrograph could possibly prove the body ornamentation illustrated earlier from Tanjung Gemok, Port Dickson [26].

During the warmest months in 2016, the corals in the study area were exposed to the bleaching incidents and thus, the areas with dead corals were wide [27]. Dead corals turned into rubbles which offered different bottom substrate to copepods, particularly for those adapted to crawl along coarser sediment such as L. cornuta. As reported earlier, harpacticoids would be able to colonise coral rubbles via water column or benthic substrate [28].
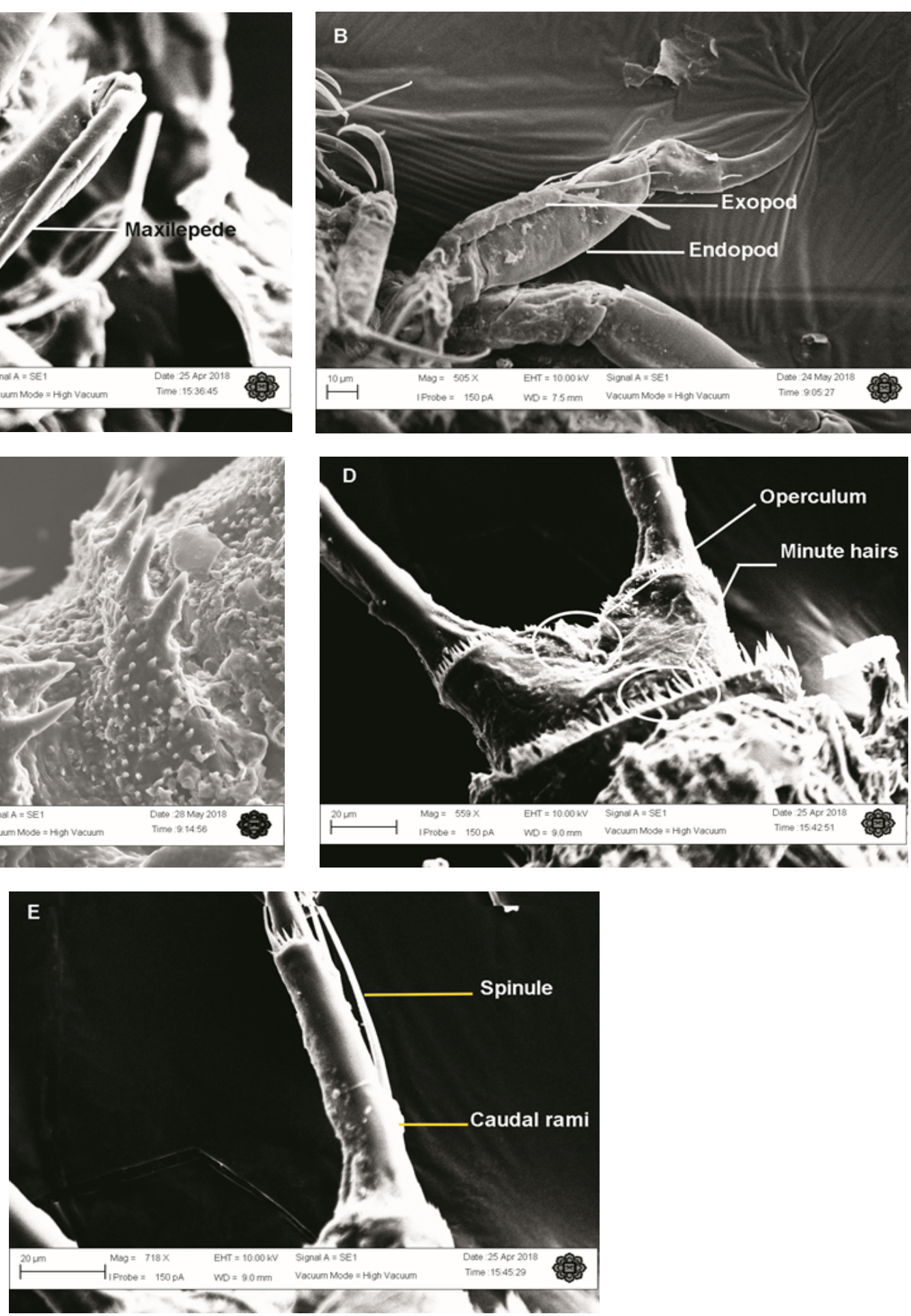

Fig.2. Laophonte cornuta, female. SEM photographs showing the detailed part of the female L. cornuta from Tioman Island Malaysia. A: Maxilliped, B: P1 exopod and endopod, C: Blunt spinules on the intergument and jigged spines along the terminal of each somites, D: Anal somite and anal operculum with ornamentation, E: Slender feature of caudal rami with single long spine at outer margin. 


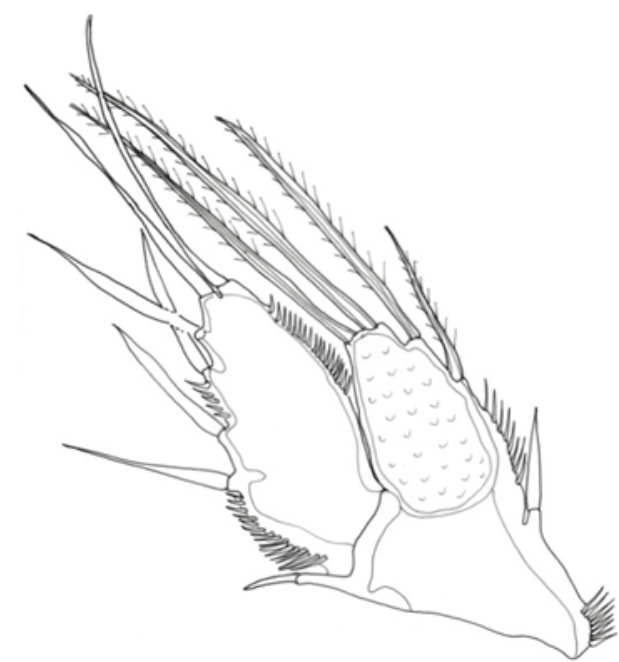

Fig. 3.Laophonte cornuta, female. P5
P5 $0.005 \mathrm{~mm}$

\section{CONCLUSION}

Overall, the morphological features agreed with the previous characters as belongs to the cornuta-type. Obvious variation was found on the denticulate spines on ends of somites and the blunt spinules distributed on the surface of somites. The ultra-structure of the surface could be the factor that helps the species to adapt to the environment in the coral area in Tioman Island during the stress condition. Further study on the behaviour response and physiological aspect of the species in relation to temperature rise and coral condition would be very important to improve our understanding on their adaptive capacity towards climate change effect. This will contribute to the sustainable management of our coral ecosystem.

\section{ACKNOWLEDGEMENT} 0479 .

This study was supported by the internal grant RIGS RIGS16-315-

\section{REFERENCES}

[1] Johan, I., Abu Hena, M.K., Idris, M.H., Arshad, A. (2013). Taxonomic composition and abundance of zooplankton copepoda in the coastal waters of Bintulu, Sarawak, Malaysia. Journal of Fisheries and Aquatic Science, 8, 472-479.

[2] Nakajima, R., Yoshida, T., Othman, B.R. \& Toda, T. (2013). First record of a blue-pigmented Acartiid copepod in the tropical coral reef waters of Malaysia. Galaxea Journal of Coral Reef Studies, 15, 27-28.

[3] Chew, L.L. \& Chong, V.C. (2016). Response of marine copepods to a changing tropical environment: winners, losers and implications. Peer $J, 4$, e2052. Doi:10.7717/peerj. 2052

[4] Zaleha, K., John, A., Asgnari, N., Al-Aama \& Fuad, M.A. (2014). Fatty acid profiling of benthic harpacticoid (Pararobertsonia sp.) exposed to environmental stresses, Malaysian Applied Biology, 43(1), $31-40$.

[5] Kassim, Z. \& Busra, I. (2012). Culture of harpacticoid copepods: Understanding the reproduction and effect of environmental factors. In Muchlisin, Z. (Ed.), Aquaculture (pp. 343-360). Rijeka Croatia, Intech Open Access Publisher.

[6] Boxshall, G. A. \& Halsey, S. H. (2004). Introduction to copepod diversity. London, UK: The Ray Society.

[7] Huys, R. \& Lee, J. (2018). Philippiphonte aspidosoma gen. et sp. n., a radically divergent member of the Laophontidae from shell gravel in the East Sea, South Korea, including a review of Folioquinpes Fiers \& Rutledge, 1990 (Copepoda, Harpacticoida). ZooKeys, 775, 15-46. DOI:10.3897/zookeys.775.26404

[8] Fuentes-Reinés, J. M. \& Suárez-Morales, E. (2017). A new species of Echinolaophonte and record of E. armiger (gurney, 1927). (Crustacea, Copepoda, Harpacticoida, Laophontidae) from the Caribbean with a key to species. Zookeys, 722, 19-36. DOI: $10.3897 /$ zookeys.722.14560
[9]

Callens, M., Gheerardyn, H., Ndaro, S.G.M., De Troch, M. \& Vanreusel, A. (2012). Harpacticoid copepod colonization of coral fragments in a tropical reef lagoon (Zanzibar, Tanzania). Journal of Marine Biology Association United Kingdom. 92(7), 1535-1545. DOI: $10.1017 / \mathrm{S} 0025315411001597$

Lee, J.M. \& Chang, C. Y. (2008). A new species of the rarely known genus Apolethon (Copepoda, Harpacticoida, Laophontidae) from brackish waters of Korea. Animal Cells System. 12(4), 249-259. DOI: 10.1080/19768354.2008.9647180

Gómez, S. \& Morales-Serna, F. N. (2013). On a small collection of Laophontidae T. Scott (Copepoda: Harpacticoida) from Mexico. I. New species and new records of Laophonte Philippi and Paralaophonte Lang. Journal of Natural History, 47(5-12), 329-380. DOI: $10.1080 / 00222933.2012 .757657$

Huys, R. (1990). A new family of harpacticoid copepods and an analysis of the phylogenetic relationships within the Laophontoidea T. Scott. Amsterdam Expeditions to theWest Indian Islands, Report 64 Bijdragen tot de Dierkunde, 60 (2): 79-120.

Walter, T. C. \& Boxshall, G. (2018). World of Copepods database. Laophonte Philippi, 1840. Accessed through: World Register of Marine Species at: http://www.marinespecies.org/aphia.php?p=taxdetails\&id=115374 on 2018-12-23

[14] Huys, R. (2001). Copepoda - Harpacticoida. In Costello, M.J. et al. (Ed.), European register of marine species: a check-list of the marine species in Europe and a bibliography of guides to their identification. Collection Patrimoines Naturels, 50: pp. 268-280.

[15] Nicholls, A. G. (1940). Marine harpacticoids and cyclopoids from the shores of the St. Lawrence, 2. Université Laval. pp.1-315

[16] Lang, K. Monographie der Harpacticiden, vol. 1-2. Hakan Ohlsson's Boktryckeri, Lund; reprinted Nordiska Bokhandeln, Stockholm. 1:1896, figs. 1-361; 2:897-1683, figs. 362-610, maps 1-378. (reprinted 1976)

[17] Ahmad, Z., Kassim, Z., Shammodin, M.S. Ayob, A.F. \& A.A. Chan. (2016, November). Ecological survey on coral bleaching using drone aerial photo at Tioman Island, Malaysia. Poster session presented at the Ecology Seminar Malaysia, Putrajaya International Convention Center, Putrajaya.

[18] Zaleha, K., Hazwani, H. H., Zainal S. \& Ishak, N. H. A. (2018). Report on five species of harpacticoid copepods from vegetative area of Sungai Pulai, Johor. Malaysian Journal of Fundamental and Applied Sciences, 14 (2), 284-288.

[19] WoRMS, World Register of Marine Species, Available from http://www.marinespecies.org. 2017.

[20] Lang, K. (1965). Copepoda Harpacticoida from the Californian Pacific Coast. Stockhom : Kungliga Svenska Vetenskapsakademiens Handlingar.

[21] Ishak, N.H.A. \& Zaleha, K. 2009. Taxanomy of a benthic copepod: Methamphiascopsis hirsutus (Thompson \& A. Scott, 1903) (harpaticoida: Diosaccidae) from Bidong Island, Malaysia. Malaysian Journal of Microscopy, 5(1), 36-41.

[22] Huys, R., Boxshall, G. A., Gee, J.M., Moore, C.G. \& Hamond, R. (1996). Marine and brackish water harpacticoid copepods, Part 1. London, UK : Linnean Society of London and the Estuarine and Coastal Sciences Association.

[23] Wells, J. B. J. (2007). An annotated checklist and keys to the species of Copepoda Harpacticoida (Crustacea). Zootaxa, 1568(1), 1-872.

[24] Fiers, F. (1986). Amsterdam Expeditions to the West Indian Islands, Report 51. Harpacticoid copepods from the West Indian Islands: Darcythompsoniidae (Copepoda, Harpacticoida). Bijdragen tot de Dierkunde, 56(2), 282-290.

[25] Gomez, S. \& Boyko, C. B. (2006). On a small collection of harpacticoids from Easter Island: the family Laophontidae T. Scott (Crustacea: Copepoda: Harpacticoida). Zootaxa, 1352, 3-70.

[26] Zaleha, K. (2008). A pictoral guide to some marine harpaticoid copepod of Malaysia. Kuala Terengganu, Terengganu: UMT Publisher.

[27] Hoegh-Guldberg, O., Mumby, P. J., Hooten, A. J., Steneck, R. S., Greenfield, P., Gomez, E., ... Knowlton, N. (2007). Coral reefs under rapid climate change and ocean acidification. Science, 318(5857), 1737-1742. DOI: 10.1126/science.1152509

[28] Callens, M., Gheerardyn, H., Ndaro, S. G. M., De Troch, M. \& Vanreusel, A. (2011). Harpacticoid copepod colonization of coral fragments in a tropical reef lagoon (Zanzibar, Tanzania). Journal of the Marine Biological Association of the UK, 92(7), 1-11. DOI:10.1017/S0025315411001597 